\title{
Is Gold Really in Action in Turkey?
}

\section{Betül Ismić}

International University of Sarajevo

\begin{abstract}
Turkey has been a significant gold importer since 1985 for three reasons: The production of gold is on a limited scale, high gold demand is pretty tied to traditions and Turkish consumers have seen gold as an effective hedge against inflation and currency weakness. Turkey's gold foreign trade can be classified into two groups as untapped gold and processed gold. Untapped gold states gold bars and processed gold presents gold jewellery. We observe from the available data that Turkey is importer of untapped gold and exporter of processed gold for almost 30 years. Since 2001, two things have changed regarding this situation in Turkey: Turkey started to produce gold through gold mining and also started to export untapped gold. World Gold Council published a report in January, 2015 named "Turkey: Gold in Action" that discusses the economic contribution of gold to Turkey's economy and the increase in gold export in last year'sraised the interest whether foreign trade of gold has an impact on economic growth. This paper aims to search the answer of this question by analyzing the impact of gold export and import on economic growth of Turkey for the period 2001:Q1-2014:Q4 with an econometric model. Augmented Dickey Fuller Test and Ordinary Least Square Method are applied to our model.
\end{abstract}

Keywords: Economic Growth, Gold Export, Gold Import. 


\section{INTRODUCTION}

According to the data of World Gold Council in 2012, global gold supply reached 4453 tons in 2012. Approximately two thirds of new gold supply each year comes from mining and remaining one third comes from the recycling of gold. So, gold mining and recycling are two ways to supply gold. Mines in the top 15 gold producing countries extracted 2177 tons of gold in 2012, \% 76 of the world total. The six largest producers are China, Australia, the United States, Russia, Peru and South Africa. These countries extracted more than half of the gold mined globally. (World Gold Council Report, 2013).Recycling of gold is the other significant source of gold supply accounting for around $36 \%$ of global supply in 2012. The location of gold recycling activity is not tied to mine production and is more likely to be linked to gold consumption. Data limitations including the lack of information on the countries, in which recycled gold is subsequently refined, mean that the gross value added (GVA) of gold recycling cannot be estimated at the country level. Instead, the analysis is limited to the global level.

Turkey has a small but growing gold mining industry. The industry started to develop in 1985 when new regulations were passed. A wave of foreign and domestic investment followed leading to the discovery and development of several large-scale gold deposits and a sharp increase in gold production. Gold production has increased almost every year since 2001 when Ovacik which is Turkey's first modern gold mine went into full-scale operation. Total production has grown from $2 t$ in 2001 to $33.5 t$ in 2013, a ten year compound annual growth rate of $20 \%$. While this growth has been impressive, it may only represent a fraction of Turkey's mining potential. The Ministry of Energy \& Resources estimate gold reserves to be 840t and resources could be as high as 6500t (WGC Turkey Report, 2015).

Over recent years, gold recycling has taken on greater significance. While mine production grows from small base, gold recycling is well established. Refiners play a key role in this fluid gold market with sizeable levels of recycled gold being imported as well as generated domestically. With a well-developed post-production supply chain, Turkey has ambitions to become a regional refining and recycling hub. Turkey has a number of large-scale refiners which refine and recycle gold. Thanks to these accredited refineries, Turkey 
imports approximately 15-20t of recycled gold annually. The majority of this gold is used to meet local demand while the rest is re-exported. Turkish culture and traditions are closely related to the gold, but it is not just local demand that is strong. Turkey's jewellery industry benefits from exports and healthy tourist trade.

Turkey's gold jewellery exports boomed after export restrictions were lifted in 1983. Turkey has been the world's second largest exporter of gold jewellery after Italy. Its biggest export market is the Middle East, but it also exports to USA, Russia and Germany. These jewellery exports have had a positive impact on Turkey's trade balance. Between 1998 and 2013, the value of Turkish jewellery exports, most of which was gold, increased from \$209mn to US3.3bn, generating valuable overseas earning. Turkey sells a lot of gold jewellery to overseas visitors as well, especially those from Russia and other Commonwealth of Independent States countries. According to the Ministry of Economy's Gold Jewellery Report published in 2012, jewellery exports and tourist demand accounted for around $70 \%$ of the jewellery sector's fabrication in 2012.(Gold Jewellery Report, 2012).

This study aims at finding the impact of gold export and import on economic growth of Turkey. We know from the data that gold's value chain makes a significant contribution to Turkey's economy. In 2012 alone, gold fabrication, consumption and recycling added at least US\$8.8bn to Turkey's economy. The value chain supports 5000 gold fabricators, 35000 retail outlets and employs about 250000 people. This does not even include 6200 people employed by gold mining companies. And between 2009 and 2013, the three largest mines together invested over US\$1bn in project expansion and ongoing capital expenditure.

\section{LITERATURE REVIEW}

Inquipy

2015/2

An economic report by World Gold Council named "The Direct Economic Impact of Gold” existsregarding gold production, gold trade and their contribution to the trade balance, economic growth and budget deficit. WGC also has specific reports for countries dealing with gold trade. Also, Central Bank of Turkey published a report in 2012 named "Gold in Turkey: Its Effect on Foreign Trade, 
Balance of Current Accounts and Economic Growth".

Besides these reports, unfortunately, we cannot find many studies regarding gold trade. The main drawback for researchers to work on this topic is the limited availability of data.

Bloch and Owusu (2012) examined the contribution of gold mining to economic growth in Ghana's economy through an empirical study. Ghana is the second-ranked African producer of gold and it is ninth in world scale and especially since 2000, gold production values and revenues rose significantly over the decade. Despite this reality, gold mining is is often depicted as having an enclave status, disconnected and isolated from the rest of the economy. This study proves against this understanding.

Kumah (2006) examines the environmental performance of the gold mining industry in developing countries and its impact on resident populations and communities.He claims that although gold industry has many drawbacks such as pollution of the environment, it can potentially confer many benefits, especially for the people of developing world by providing employment and foreing exchange.

Keatley (1992) has a conference proceeding regarding Africa's gold potential. There are several other studies that show the contribution of mining sector to sustainable economy and these studies also include gold mining. Jonah (1987), Sachs and Warner (1999), Humphreys (2000) can be given as an example.

\section{DATA, METHODOLOGY AND MODEL}

In the study, for the econometric model, quarterly indicators of economic growth, export of untapped gold and import of untapped gold are employed for the period from 2001: Q1 to 2014: Q3. Economic growth is represented as annual change of seasonally and calender adjusted expenditure on the gross domestic product.(base year 1998). This data is sourced from Central Bank of Turkey. Untapped gold import and untapped gold export data sets are sourced from Turkish Statistical Institute (TÜIK). The existence of seasonality is tested through dummy variables and we could not find any seasonality in our data set. 
The aim of this study is to explore the impact of gold export and gold import on economic growth by employing Ordinary Least Squares Method. The model can be described as follows:

$$
\mathrm{Y}_{\mathrm{t}}=\beta_{0}+\beta_{1} \mathrm{EXPORT}_{\mathrm{t}}+\beta_{2} \mathrm{IMPORT}_{t}+\Sigma_{\mathrm{t}}
$$

where Y denotes economic growth rate of GDP, EXPORT denotes export of untapped gold, IMPORT denotes import of untapped gold and $\Sigma_{t}$ is the error term.

In time series analysis, if a series does not have a stochastic trend and is stationary, it is said to be integrated of order zero or I $(0)$. If a series has random walk trend, it is said to be integrated of order one or I(1) (Stock \& Watson, 2007). The null hypothesis for the nonstationary is tested. The results of the Augmented Dickey Fuller for unit root are provided on Table 1.

\begin{tabular}{|l|l|l|l|}
\hline \multicolumn{4}{|c|}{ Table 1: ADF Test Results: Level } \\
\hline & $\begin{array}{l}\text { ADF TEST } \\
\text { RESULT }\end{array}$ & $\begin{array}{l}\text { ADF CRITICAL } \\
\text { VALUE (\%1) }\end{array}$ & $\begin{array}{l}\text { ADF CRITICAL } \\
\text { VALUE (\%5) }\end{array}$ \\
\hline $\mathrm{Y}$ & -3.7123 & -3.5601 & -2.9176 \\
\hline EXPORT & -7.7351 & -3.5574 & -2.9165 \\
\hline IMPORT & -3.0074 & -3.5654 & -2.9199 \\
\hline
\end{tabular}

The findings reveal that variables Y, EXPORT and IMPORT can be considered as stationary at level. Thus, these variables are I( 0$)$. In time series analysis, if the data set are not stationary and we estimate it with ordinary least squares, results can direct us to an econometric term "spurious regression". Spurious regression is the one in which time series variables are non-stationary and results of regression are deceptive. Many time series techniques are developed for this reason after 1980s. In our data set, since all variables appear to be stationary, the results of ordinary least square estimation will be reliable. This is the reason we employ this methodology in our study. Estimation $2015 / 2$ results are provided on Table 2. 


\begin{tabular}{|l|l|l|}
\hline \multicolumn{3}{|c|}{ Table 2: Estimation Results } \\
\hline & COEFFICIENTS & P-VALUES \\
\hline C & 5.481 & 0.0000 \\
\hline EXPORT & -0.006 & 0.0367 \\
\hline IMPORT & -0.011 & 0.0554 \\
\hline R2 & 0.621 & \\
\hline Adjusted R2 & 0.599 & \\
\hline Lagrange Multiplier Test & 9.2956 & 0.0561 \\
\hline $\begin{array}{l}\text { Breush-Pagan-Godfrey } \\
\text { Test }\end{array}$ & 1.266 & 0.5010 \\
\hline Akaike Value & 6.2535 & \\
\hline
\end{tabular}

In order to examine the reliability of the model, the effects of heteroscedasticity and autocorrelation are examined by running several diagnostic tests. For heteroskedascity, Breush-Pagan-Godfrey test is employed and existence of homoskedascity is confirmed. For the simplicity of interpretations, p-values of the tests and coefficients are provided. If $\mathrm{p}$-value is smaller than 0.05 , we conclude that we reject null hypothesis. For Breush-Pagan test null hypothesis shows the existence of homoskedascity and alternative hypothesis shows the existence of heteroskedascity. Since p-value: $0.5010>0.05$, we cannot reject null hypothesis. Similar result is valid for autocorrelation. To detect autocorrelation, we run Lagrange Multiplier test. The null hypothesis is "there is no autocorrelation in the model" can not be rejected since p-value: $0.06>0.05$. For autocorrelation, we use " 4 " lags for the test, because quarterly data set is used in our analysis. It makes DW test results invalid, because DW is calculated by only "1" lag. $\mathrm{R}^{2}$ measures how well OLS regression line fits the data. Adjusted $\mathrm{R}^{2}$ which is more suitable for comparing models with different numbers of independent variables for our model is around $59 \%$. It means that the model (independent variables) explains $59 \%$ of the variance in dependent variable.

P-values of coefficients Export and Import show that both variables are significantly affecting economic growth at $5 \%$ significance level. One percent increase in export decreases economic growth 0.006 percent. One percent increase in import decreases economic growth by 0.01 percent. First of all, magnitudes of coefficients are quite low since economic growth can not only be explained by these two variables. Omitted variables can decrease the power of the 
model. Second of all, negative signs of variables can be explained by the structure of data set. In our statistics database, only untapped (raw) gold import and untapped gold export data are available and as our study proves that there is not positive contribution to economic growth from untapped gold. Gold production and processed gold can contribute to our economic growth much better. As we expressed in introduction part, Turkey has been one of the largest exporter of gold jewellery and since 2001, we started to produce our own gold through mining in Ovacık, İzmir.

\section{CONCLUSION}

This study is an ongoing work. The biggest limitation is the availability of the announced data sets. Our next goals can be summarized as follows: We now have export of processed gold export on annual basis for the period of 1990-2012. During this period, we have three financial crises in Turkey, so data set is pretty affected by structural breaks. We can eliminate these structural breaks from data set through some techniques, but it is loss of information as well. If monthly or quarterly data of processed gold export is calculated by Turkish Statistical Institution, we can also search for the effect of processed gold export on economic growth.

As we expressed before, gold production started in 2001 in Turkey. We have annual data for 2001-2013 period and monthly data by Borsa İstanbul for 2008-2013 period. For such a short period of time, it is hard to catch some trend at this point, but in five years, the effect of gold production on economic growth of Turkish economy can be calculated as well. We expect that this production-based approach will provide much better models. 


\section{REFERENCES}

Aktaş, Zelal, Aldan, Altan, Aydın, Faruk(2012). "Türkiye'de Altın: Dış Ticaret, Cari İşlemler Dengesi ve Büyüme Üzerine Etkisi”, TCMB Ekonomi Notları

Bloch, R., Owusu, G.(2012). "Linkages in Ghana's Gold Mining Industry”, Resources Policy, 37, 434-442

Humphreys, D. (2000). "Mining as a Sustainable Economic Activity", presented at Informal Seminar at OECD, The Journal 6-11 Article (CEPMLP Website)

Jonah, S.E.(1987). "The Impact of economic Recovery Programme on the Mining Industry in Ghana", In proceedings of seminar on mineral sector in Ghana, Minerals Commission

Keatley, M., "Africa's Gold Potential", Speech at the World Gold Conference in London, International Finance Cooperation, 1192

Kumah, A. (2006) "Sustainability and Gold Mining in the Developing World", Journal of Cleaner Production, 14, 315-323

Sachs, J.D., Warner, A.M. (1999) "Natural Resource Intensity and Economic Growth, Development Policies in Natural Resource Economics"

Stock, J.H., Watson, W.M. (2007). Introduction to Econometrics, 2/E. Prentice Hall The Direct Economic Impact of Gold (2013), World Gold Council Report

Turkey: Gold in Action (2015), World Gold Council Report 